\title{
An Overview of the Copyright Protection Laws in Bangladesh-A Critical Analysis of the Copyright Act, 2000 with Its Loopholes and Recommendations
}

\author{
Muhammad Farhad Hosen \\ Department of Law, International Islamic University Chittagong, Chittagong, Bangladesh \\ Email:farhadlex@gmail.com
}

How to cite this paper: Hosen, M. F. (2017). An Overview of the Copyright Protection Laws in Bangladesh-A Critical Analysis of the Copyright Act, 2000 with Its Loopholes and Recommendations. Beijing Law Review, 8, 191-211.

https://doi.org/10.4236/blr.2017.82011

Received: May 14, 2017

Accepted: June 26, 2017

Published: June 29, 2017

Copyright $\odot 2017$ by author and ScientificResearch Publishing Inc. This work is licensed under the CreativeCommons Attribution International License (CC BY 4.0).

http://creativecommons.org/licenses/by/4.0/ (c) (i) Open Access

\begin{abstract}
Nowadays, it goes without saying copyright is one of the most significant field of Intellectual Property related to the exclusive monopoly rights in the arena of literature, dramatics, musical, artistic, cinematograph and sound recordings. Day by day the importance of copyright is increasing whereas the lacking of necessary measures to protect copyrights are going to be difficult because of our lack of enforcing mechanisms and insufficient laws and plagiarizing activities although we have Copyright Act 2000. To protect the rights and privileges of the author or the creator of Copyright works, footsteps and different measures of the Government should be increased and piracy must be stopped by establishing strong enforcement agency. To protect the copyrights of the creator especially of the author, the govt. should come forward to enforce the rules and regulations which have been incorporated in the Act of 2000 and some amendments are also required to enforce. By this research, the researcher tries to pick out the copyright status of Bangladesh, an overview of the Copyright Act 2000, and the common barriers and solutions of those barriers related to the copyright position in Bangladesh.
\end{abstract}

\section{Keywords}

Intellectual Property, Copyrights, Copyright Society, Piracy, Remedies

\section{Introduction}

Copyright is a legal concept enacted by the legislator of the state, giving the creator of an original work exclusive right to it, usually for a limited time. ${ }^{1}$ Generally, it indicates "the right to copy", but also gives the copyright holder the right to be credited for the work and to determine who may modify the ${ }^{1}$ Sections 24-38, Copyright Act 2000 (Act No. XXVIII). 
work to other forms, who may perform the work, who may financially benefited from it, and other related exclusive monopoly rights. It is one kind of intellectual property (like the patent, the trademark, and the trade secret) applicable to any expressible form of an idea or information that is substantive and separate. In fact, it is a bundle of rights including, inter alia, rights of reproduction, communication to the public, adaptation and translation of the work. ${ }^{2}$ The ultimate object of the copyright law is to encourage authors, artistic, composers and designers to create original works by rewarding them with the exclusive monopoly right for a specified period of time to exploit monetary gain and reputation for perpetually.

\section{Methodology}

The paper reflects an overview of copyright and its protection under the Copyright Act 2000 of Bangladesh. In carrying out the paper I depended on the primary and secondary sources. The article is basically literary based with an overall mixture of analytical reasoning. The article is based on the existing copyright laws, international agreements, case references and different books, articles of prominent jurists, data of relevant organizations, newspapers and web sites.

\section{Copyright Law of Bangladesh: An Overview}

It contains different provisions relating to computer programs and digital media copyrights, database, rental rights, cinema, literature related rights, dramatic rights, musical rights, artistic rights, cinematograph rights, sound recordings rights, broadcasting rights, performer's rights, phonograms rights, etc. It also provides a number of provisions for uses of protected works without seeking permission from authors for the purpose of fair dealings, such as private study, private use, research, criticisms, review, reporting current events in a newspaper, magazine or similar periodical, in cinematograph films by broadcast or by photograph.

The law also provides some other provisions to use a protected work without authorization from an author in cases of official gazettes, reports of various commissions, committees' boards or councils appointed by government or other similar bodies, if it is not expressly prohibited to publish. Similarly, a number of some other provisions also exist in law under which users are given powers to use freely of the protected works in cases of sound recordings, cinematographic film, computer programs under certain exceptional cases.

Copyright is a property right that subsists in certain specified types of works as provided in the act for the owner or creator of those specified subsists. The owner of the copyright subsisting in his work the exclusive right to do certain acts in relation to the work such as making a copy, broadcasting or selling copies to the public. These are examples of the acts which are directly restricted by ${ }^{2}$ P. Narayanan (2001), “Intellectual Property Law (3 ${ }^{\text {rd }}$ Edition)”, Kolkata-New Delhi: Eastern Law House, p. 251. 
copyright. The owners of the copyright can control the exploitation of his work, for example by making or selling copies to the public or by granting permission to another to do this in return for a specified payment or not. If a person executes one of the acts restricted by copyright act without the permission or license of the copyright owner, the latter can sue for infringement of his copyright and mandatorily can obtain remedies, for example damages and an injunction under the Copyrights Act, 2000.

Copyright law provides a number of provisions for limitations. Limitation refers to terms of copyright. Copyright is not a perpetual property unlike other movable or immovable properties. ${ }^{3}$ The ownership of copyright is limited to a fixed period of time, after expiry of which copyright does not subsist and it becomes a public domain work and then any person or individual can use it without observing any legal obligations. The term may differ from country to country. It may be 70 or 60 or 50 years but it should be minimum 50 years in major work, in accordance with international copyright law i.e., the Berne Convention of WIPO ${ }^{4}$ for the protection of literary and artistic works of which Bangladesh is a member country. ${ }^{5}$

\section{Interpretation Clause}

\section{a. Intellectual Property}

Generally, the term "Intellectual Property" has come to be internationally recognized as covering patents, industrial designs, copyright, trade mark, know-how and confidential information. Patents, designs and trademarks used to be considered as different kinds of Intellectual Property. But when copyright and confidential information were included the term "Intellectual Property", though a litthe high sounding is a more appropriate description for this class of property. Intellectual Property (IP) can be defined as the creation of human brain or mind or intellect as for it is called Intellectual Property.

\section{b. Copyright indicates}

Copyright is one of the sub-division of intellectual property law. It is a group of exclusive monopoly rights given by the Copyright Law to the owner or creators or authors of the following works: literary (including computer programs); dramatic; musical; artistic works and producers of cinematograph films and sound recordings.

It also indicates the exclusive right to reproduce or authorize others to reproduce artistic, dramatic, literary or musical works. Copyright means the exclusive right to apply a design to any article in any class in which the design is registered. ${ }^{6}$ Further, copyright of a work is the exclusive right to multiply copies of the work, not merely a right to do so in common with others. ${ }^{7}$

In the Act of 2000, copyright means any right, to do or authorize the doing of

${ }^{3}$ Section 24, Copyright Act 2000.

${ }^{4} \mathrm{WIPO}$ indicates World Intellectual Property Organization.

${ }^{5}$ Article 45, Berne Convention on WIPO.

${ }^{6}$ Section 2(4), Patents and Designs Act, 1911.

${ }^{7}$ Sims vs. Marrayat, 17 CB 281; 20 LJQB; 79 ECL 281. 
any of the concerned acts in respect of a work thereof, namely: ${ }^{8}$

i. Literary, dramatic, or musical work except a computer program: Reproducing the work in any material form, issuing copies of the work to the public, performing the work in the public, producing, reproducing, performing or publishing any translation of the work, broadcasting of the work or making any adaptation of the work;

ii. Computer program: Doing any of the acts mentioned in the preceding paragraph and selling or giving on hire, or offering for sale or hiring any copy of the computer program;

iii. Artistic work: Reproducing the work in any material form, publicizing the work to the public, issuing copies of the work to the public, including the work in any cinematograph film, broadcasting of the work or making any adaptation of the work, etc.;

iv. Cinematograph film: Making a copy of the work, including a photograph of any image forming part thereof in VCP, VCR, DVD or any other form, or selling or giving on hire, or offering for sale or hiring any copy of the film in VCP, VCR, DVD or any other form and publicizing and displaying among general public any auditory or visual copy of the film in VCP, VCR, DVD or any other form; and

v. Sound recording: Making any other sound recording embodying it, or selling or giving on hire, or offering for sale or hiring any copy of the sound recording, or communicating the sound recording to the public, etc.

Copyright protection covers expressions of ideas rather than the ideas themselves. ${ }^{9}$. Under section 15 of the 2000 Act, copyright protection is conferred on original ${ }^{10}$ literary works, dramatic works, musical works, artistic works, cinematograph films and sound recording. It extends to the computer program also. ${ }^{11}$

Copyright refers to a bundle of exclusive rights vested in the owner of copyright. ${ }^{12}$ Above rights can be exercised only by the owner of copyright or by any other person who is duly authorized by license in this regard by the owner of copyright. These rights include the right of adaptation, ${ }^{13}$ right of reproduction, right of publication, right to make translations, communication to public, etc.

\section{c. Owner of the Copyright}

The owner of copyright work is generally, the person who creates the work, more specifically the author of the work. There can be exceptions to this general principle. Such general recognition and exception are laid down in the Act of $2000 . .^{14}$

- If the author is employed by newspaper, magazine, etc. under a contract of ${ }^{8}$ Section 14, Copyright Act, 2000 (herein referred as to the 2000 Act) Copyright Protection Situation in Bangladesh.

${ }^{9}$ Article 9.2, TRIPS Agreement 1994.

${ }^{10}$ Original means, that the work has not been copied from any other source.

${ }^{11}$ Before the enactment of Copyright Act, 2000, copyright protection was not available to the computer program.

${ }^{12}$ Supra note 2.

${ }^{13}$ Adaptation is generally understood as the modification of a work to create another work, for example, adapting a novel to make a film. Hossain.

${ }^{14}$ Section 17, Copyright Act 2000. 
service, the proprietor will be the first owner in the absence of an agreement to the contrary in the case of a literary, dramatic or artistic work. ${ }^{15}$

- Where a photograph is taken or a painting or portrait drawn or an engraving or a cinematograph film made for valuable consideration at the instance of a person, such person is the first owner. ${ }^{16}$

- Where any address or speech is delivered in public, the person delivering such address or speech is the first owner of it but another will be the first owner if it is made on behalf of him. ${ }^{17}$

- In case of government work, the government is the first owner. ${ }^{18}$

- In case of a work made or published by or under the direction or the control of any local authority, such authority is the first owner. ${ }^{19}$

- In case of a work made or published to which, the provisions of section 68 of this Act, apply, by or under the direction or the control of any international organization, such organization is the first owner. ${ }^{20}$

- In case of a computer program, the person or persons or institution appointed for creating the program, will be the first owner. ${ }^{21}$

\section{A Sketch of the Copyright Act 2000}

\section{a. Copyright Protection}

Copyright law protects only the form of expression of ideas of the creator, not the ideas themselves. It protects the owner of property rights against those who copy or otherwise take and use the form in which the original work was expressed by the creator or author. ${ }^{22}$ The law may state that the author of an original work has the right to prevent other persons from copying or otherwise using his work. ${ }^{23}$ So a created work is considered protected as soon as it exists, and a public register of copyright protected works is not necessary. ${ }^{24}$

In Bangladesh in order to get copyright protection the owner of the work should register it under Copyright Register in accordance of the law. It is relevant that under the 2000 Act, registration is optional; not compulsory to get copyright protection under Copyright Act. At the same time it is also true that copyright protection is legally ensured to the copyright owner by registration; certificate of registration of literary, dramatic or artistic work is considered as a prima facie evidence when any dispute arises. ${ }^{25}$ Any other person than a registered owner, can get copyright protection by grant of license either by voluntary or compulsory license or any other means like; assignment. Here the provisions

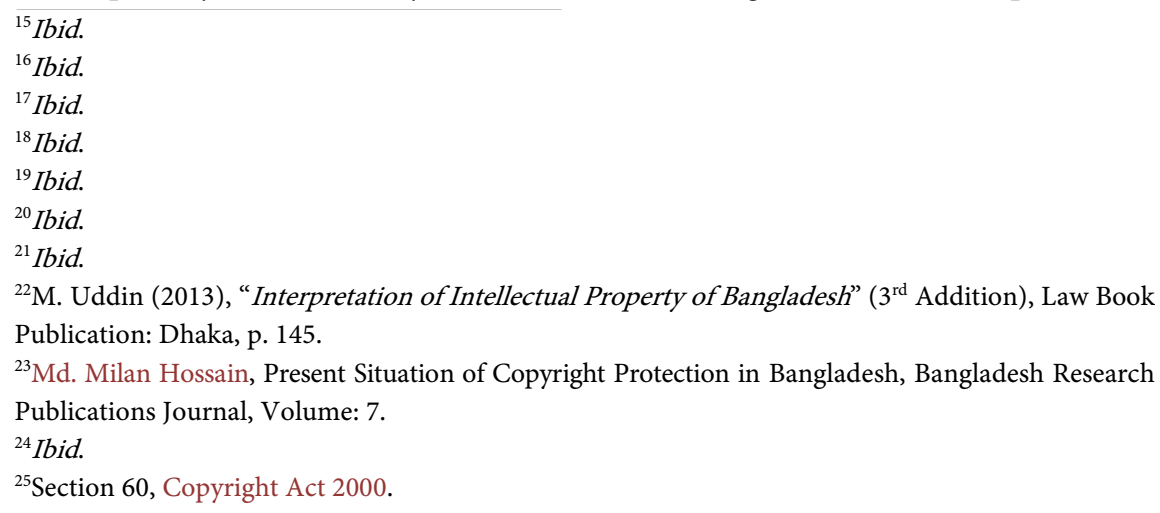


of infringement and remedies of copyright infringement also play an imperative role in providing copyright protection to the copyright owners.

\section{b. Conditions for Getting Copyright Protection}

Copyright comes into existence as soon as a work is created and no conventionalism is required to be completed for acquiring such monopoly right under the said Act of 2000. However, facilities exist for having the work registered in the Register of Copyrights maintained in the Copyright Office under the Ministry of Culture Affairs. ${ }^{26}$ The certificate issued by the Registrar of Copyright under observing the prima-facie evidence of ownership of copyright. The Copyright Office has been set up to provide registration facilities to all types of works ${ }^{27}$ and is headed by a Registrar of Copyright. ${ }^{28}$ In order to get copyright the owner has to show that the work is original; it is immaterial whether the work is wise or foolish, accurate or inaccurate or whether it has or has not any literary merit. ${ }^{29}$ In order to qualify for copyrights the works apart from being original, should:

- In the case of published work, it has to be published first in Bangladesh but if it is first published ${ }^{30}$ in foreign country, the author must be a citizen of Bangladesh or domicile in Bangladesh at the date of publication, or where the author is dead at the time of publication and the work is published after his death, the author must be a citizen of Bangladesh or domicile in Bangladesh at the time of his death. ${ }^{31}$ It is important to note that if any work is published in Bangladesh and any other country simultaneously, the work should be considered to be first published in Bangladesh. ${ }^{32}$ The work shall be considered to be simultaneously published if the difference of days between the publication in Bangladesh and publication in any: ${ }^{33}$

- In case of unpublished work, the author is on the date of making of the work a citizen of Bangladesh or domicile in Bangladesh. ${ }^{34}$ This does not apply to works of architecture. ${ }^{35}$

- In the case of cinematographic work, the office or residence of the produce must be in Bangladesh at the time of making the work, the office or residence of the producer must be in Bangladesh at the time of making the whole or substantial part of the work.

- In the case of any architectural artistic work, the work must be located in

${ }^{26} \mathrm{Md}$. Milan Hossain, Present Situation of Copyright Protection in Bangladesh, Bangladesh Research Publications Journal, Volume: 7.

${ }^{27}$ Work means a literary, dramatic, musical, artistic work or cinematograph film or sound recording or broadcasting as per section 2(11), the 2000 Act.

${ }^{28}$ Located at National Library Building $\left(2^{\text {nd }}\right.$ Floor $), 32$, Justice S. M. MorshedSarani, Agargaon, Sher-e-Bangla Nagar, Dhaka.

${ }^{29}$ Azam Mohammad Monirul (2008), Intellectual Property, WTO and Bangladesh, Dhaka: New Warsi Book Corporation, $1^{\text {st }}$ edn, p. 193.

${ }^{30}$ Publication means making a work available to the public by issue of copies or by communicating the work to the public as per section 3 of the Act, 2000.

${ }^{31}$ Section 15(2)(a), Copyright Act 2000.

${ }^{32}$ Ibid.

${ }^{33}$ Section 5, Ibid.

${ }^{34}$ Section 15(2)(b), Ibid Copyright Protection Situation in Bangladesh.

${ }^{35} \mathrm{Ibid}$. 
Bangladesh. ${ }^{36}$

\section{c. Registration Procedure of Copyright.}

The Act of $2000^{37}$ and the Copyrights Rules of $2006^{38}$ set out the procedure for the registration of a copyright work. In order to get copyright registration, the author or publisher of, or the owner of, or other person interested in the copyright in any work can make an application to the Registrar for entering particulars of the work in the Register of Copyrights. ${ }^{39}$ The other steps for the registration are as follows:

- Application is to be made on Form II in triplicate as prescribed in the First Schedule of the 2000 Act. $^{40}$

- Separate application is to be submitted for registration of each work. ${ }^{41}$

- Each application is to be accompanied by the prescribed fee mentioned in the Second Schedule of the Rules. ${ }^{42}$

- The applications should be signed by the applicant or the advocate in whose favour a Vakalatnama or Power of Attorney has been executed. ${ }^{43}$

- To serve notice of concerned application to every person who has any interest in the subject matter of that application. ${ }^{44}$

- If the Registrar receives any objection, he may after holding such inquiry as he deems fit, enter such particulars of work in the Register of Copyrights, and issue a certificate of such registration to the applicant. If he refuses to enter, he has to record in writing the reasons of refusal. ${ }^{45}$

\section{d. Assignment}

An assignment is in spirit a transfer of ownership even if it is partial. It is the voluntary change of ownership of the work. Basically, copyright may be assigned to any third party under subject to the certain restrictions of the Act. It indicates that the owner of the copyright transfers it to another person or entity, who becomes the owner of the said copyright. An assignment directs something more than mere subrogation and vests in the insurer the assured's interest, rights and remedies in respect of the subject matter and substance of the insurance. ${ }^{46}$ In such a case, therefore, the insurer by virtue of the transfer or assignment in his favors will be an apposition to maintain a suit in his own name against third parties. ${ }^{47}$

The owner of the copyright in an existing work or the prospective owner of the copyright in a future work may assign to any person the copyright wholly or

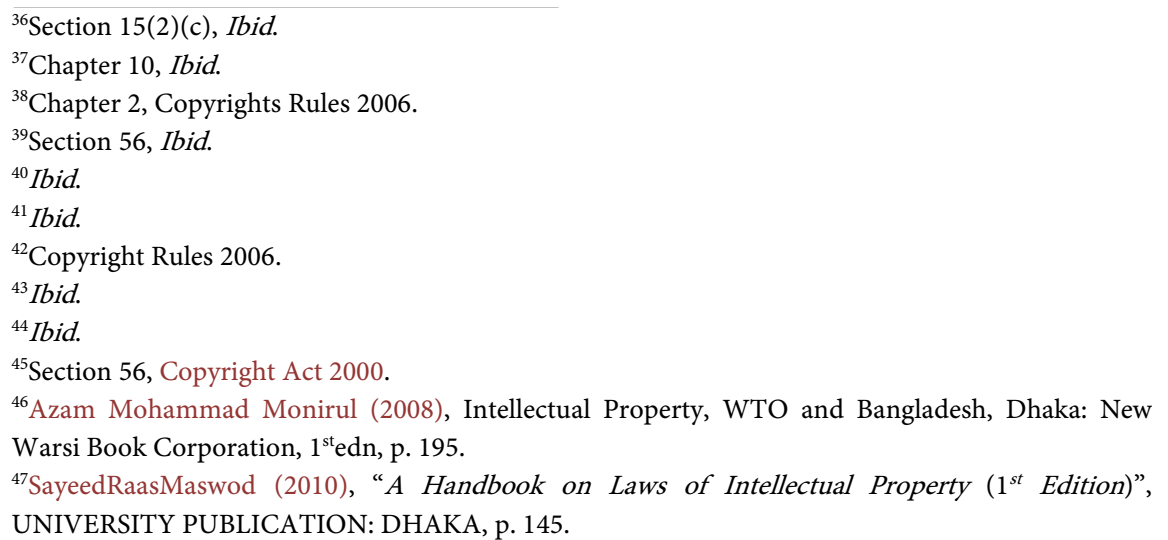


partially and either generally or subject to limitation and either for the whole term of the copyright or any part thereof. ${ }^{48}$

In order to assign a copyright the certain manner must be followed. ${ }^{49}$ The mode of assignment is in the following ways:

1) It shall be in writing signed by the assignor or by his duly authorized agent. ${ }^{50}$

2) It shall identify the specific works and specify the rights assigned and the duration and territorial extent of such assignment. ${ }^{51}$

3) It shall also specify the amount of royalty payable, if any, to the author or his legal heirs during the existence of the assignment. ${ }^{52}$

4) The assignment shall be subject to revision, extension or termination based on terms mutually agreed upon by the parties. ${ }^{53}$

5) Where the assignee does not exercise the rights assigned to him within a period of one year from the date of assignment, the assignment in respect of such rights shall be deemed to have lapsed after the expiry of the said period unless otherwise specified in the assignment. ${ }^{54}$

6) If the period of assignment is not stated, the duration of the assignment shall be deemed to be five years from the date of assignment. ${ }^{55}$

7) If the territorial extent of the assignment is not specified, it shall be presumed to be extended to the whole of Bangladesh. ${ }^{56}$

However, the author of a work may relinquish all or any of the rights comprising the copyright in the work by giving notice in the prescribed form to the Registrar of Copyrights. ${ }^{57}$ As per section 20 of the 2000 Act, the Copyright Board is authorized to deal with any dispute regarding the assignment of copyright where the procedure also been prescribed. In this case, the aggrieved assignor must make a complaint and on satisfaction, the Board may pass an order of revocation of assignment but not before the expiry of five years from the date of such assignment. ${ }^{58}$

\section{e. License}

Licensing means the owner or creator of the copyright holds ownership but he can authorizes a third party to perform certain acts which covered by his exclusive economic rights, usually for a specific period of time and for a specific purpose. ${ }^{59}$ For example, the author of a novel may grant a license to a publisher to make and distribute copies of the novel in the market. At the same time, the au- 
thor may grant a license to a film producer to make a film based on the novel. ${ }^{60}$

There are certain provisions relating to the transferring copyright through license have been incorporated in the Act of 2000. Like in an assignment of copyright, a license will be writing and can be limited in terms of either the scope or duration or both. If the duration and geographical limit is not in the license deed, then it will be presumed for five years and limited within Bangladesh. ${ }^{61}$

\section{f. Duration of Copyright Protection}

Copyright of the creator does not continue for the time of indefinitely. ${ }^{62}$ The law provides for a period of time or a duration, during which the rights of the copyright owner exist and at that time, the owner can exclusively enjoy the right. The duration begins from the date of creation of the work. The duration which extends to some period after the death of the author or creator with a view to enabling the author's or creator's successors to have economic benefits after his death and safeguarding the investments made in the production and dissemination of his works.

In those countries who are the party to the Berne Convention, and in many other countries except the member of Berne Convention, the duration of copyright provided for by national law is the life of the author and not less than fifty years after the death of the author. In recent years, a tendency has emerged towards lengthening the term of protection. ${ }^{63}$

In Bangladesh the term of copyright varies according to the nature of the work and whether the author is a natural person or a legal person e.g. a corporation, Government Institution, etc., or whether the work is anonymous or pseudonymous. Sections $24-38$ of the 2000 Act deal with the term of protection as follows:

1) in cases of literary, artistic, musical, dramatic works, the terms is 60 years from the beginning of the calendar years next following the year in which the author dies (Life +60 years); ${ }^{64}$

2 ) in cases of photograph, the term is 60 years from the beginning of calendar year next following the year in which the photograph is published (60 years from publication); ${ }^{65}$

3 ) in case of cinematographic film, the term is 60 years following the year in which the film is published (60 years from publication); ${ }^{66}$

4) in cases of Govt. works, it is 60 years from publication (60 years from publication); ${ }^{67}$

$5)$ in cases of local authority, the term is 60 years from first publication $(60$

${ }^{60}$ Ibid.

${ }^{61}$ Section 53, Copyright Act 2000.

${ }^{62}$ WIPO Intellectual Property Handbook. Policy, Law and Use, WIPO Publication No. 489, p.50, p. 2.225 .

${ }^{63} \mathrm{Md}$. Milan Hossain, Present Situation of Copyright Protection in Bangladesh, Bangladesh Research Publications Journal, Volume: 7.

${ }^{64}$ See sec 24, Copyright Act 2000.

${ }^{65}$ See Sec 28 , ibid.

${ }^{66}$ See Sec 26, ibid.

${ }^{67}$ See Sec 30, ibid. 
years from first publication); ${ }^{68}$

6) in case of sound recordings, it is 60 years from publication (60 years from publications); $;^{69}$

7) in case of works of international organizations, the term is 60 years from 1st publication (60 years from first publication) $;^{70}$

8 ) in case of broadcasting, the term is 25 years from the beginning of the calendar year next following the year in which the broadcasting is made (25 years from broadcasting); ${ }^{71}$

9) in case of performance, it is 50 years from the beginning of the year next following the year in which the performance is made (50 years from the first performance is made) $;^{72}$

10) in case of published edition (typographical arrangement), the term is 25 years from the beginning of the calendar year next following the year in which the edition is first published ( 25 years from the first publication); ${ }^{73}$

11) in case of joint authorship of a work, the term will be 60 years from the death of last surviving author (60 years from death of the last surviving author).$^{74}$

Apart from the protection of above mentioned works, Copyright Act also provides for the protection of broadcast reproduction rights for a term of twenty years from the beginning of the calendar year next following the year in which the broadcast is made ${ }^{75}$ and protection of performer's rights, which extends to fifty years from the beginning of the calendar year next following the year in which the performance is made. ${ }^{76}$

\section{g. Infringement}

Simply, commercial exploitation of any work without the proper authorization of its author or creator shall constitute a crime of infringement such as; unauthorized copy, reproduction or use of copyright raises the question of infringement. In order to ensure exclusive right to the owner of a work, there must have certain provisions as regards infringement. Which acts create infringement if it is well defined by law; it will be easy on part of the owner to take necessary actions against the offender and thus the rights and interests of the owner shall be protected.

The present law of copyright also ensures protection by inserting the provisions of infringement. Copyright in a work is deemed to be infringed: $:^{77}$

When any person, without a license from the proper authority e.g., owner of the copyright or the Registrar of the copyright or in contravention of the conditions of a license granted or any conditions imposed by a competent authority

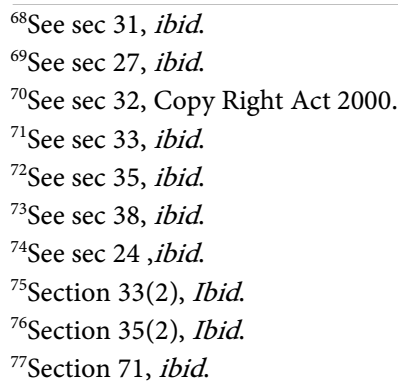


under Act:

- does anything, the exclusive right to do which is conferred upon the owner of the copyright; or $^{78}$

- permits for profit any place to be used for communicating the work to the public where such communication constitute an infringement of the copyright in the work, unless he was not aware and had no reasonable ground for believing that such communication to the public would be an infringement of copyright. $^{79}$

Copyright infringement may also arise if any person does any of the following acts: $^{80}$

- makes for sale or hire, or sells or lets hire or by way of trade displays or offers for sale or hire any infringing copies of the work; or $^{81}$

- distributes, either for the purpose of trade or to such an extent as to affect prejudicially the owner of the copyright, any infringing copies of the work, or

- exhibits to public by way of trade any infringing copies of the work, or ${ }^{82}$

- imports in Bangladesh any infringing copies of the work. ${ }^{83}$

The present copyright law at the same time provides certain cases where no infringement can arise. ${ }^{84}$ Several exceptions are as follows:

1) Fair use of a literary, dramatic, musical or artistic work for the purpose of private study or private use including research; or criticism or review. ${ }^{85}$

2) Fair use of a literary, dramatic, musical or artistic work for the purpose of reporting current events in a newspaper, magazine, or similar periodical or in a cinematograph film or by means of photograph. ${ }^{86}$

3) Reproduction for use in judicial proceedings and for use of members of the legislature, etc. ${ }^{87}$

\section{h. Copyright Piracy}

I was very young when my school friends took me to Reazuddin Bazaar (in the commercial capital of Bd) to get new MP3s and DVDs. I wondered at that time that how those MP3s had all the songs by Guns \& Roses and Eric Clapton in just Tk. 30 - 40. Also, the latest Hollywood movies were available for the same price. I told my friends referring to the people who were selling those MP3s and DVDs, "These are unbelievable and miracle matters". "No", one of my friends replied, and added that "This is all illegal". Today, it is called as piracy.

Piracy is considered to be the illegitimate use of materials held by copyright. ${ }^{88}$ The unauthorized copying or reproduction of copyright ingredients for com-

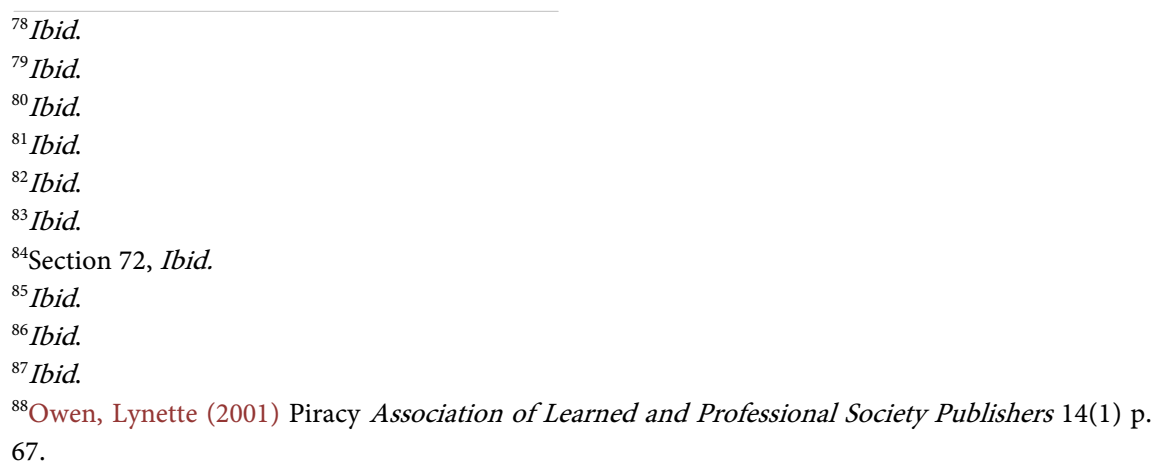


mercial objects and the unauthorized commercial dealing in copied ingredients is treated as copyright violation or directly as piracy. It affects all of the elements involved in the creation; production and distribution of intellectual works together constitute copyright system. ${ }^{89}$ Piracy primarily targets software, film and musical works. However, the unauthorized copying of books and other text works remains common, especially for educational repurposes. The pirated copies usually sold at reduced prices, thereby undermining the original author's and investor's possibility of obtaining a just moral and economic reward for their work and investment and thus the author's and investor's loose their interest in creation new literary, dramatic or artistic work. ${ }^{90}$

Copyright piracy is a great problem in Bangladesh. Here its rate is the highest amongst the world. ${ }^{91}$ Most of the people do not realize that the copyright of a work (literary, artistic or dramatic) belongs to the creators or author; not to them; if they copy it without authorization, it constitutes an infringement or an offense under specified laws of the state.

\section{i. Remedies}

The enforcement obligations in the TRIPS Agreement provide a comprehensive foundation for the development of civil, administrative and criminal procedures and remedies necessary for effective enforcement against traditional forms of copyright piracy. Articles 41-61 of TRIPS Agreement provide enforcement provisions as regards copyright. Some of them are as follows:

(i) effective action against infringements, including expeditious remedies to prevent infringements and remedies which constitute a deterrent to further infringements. ${ }^{92}$

(ii) adequate civil or administrative procedures and remedies, including the availability of civil injunctions $;{ }^{93}$ the disposal or destruction of pirate goods; ${ }^{94}$ and the disposal or destruction of materials and implements the predominant use of which has been in the creation of the infringing goods. ${ }^{95}$

(iii) adequate criminal procedures, including deterrent penalties; ${ }^{96}$ the availability of seizure, forfeiture and destruction of infringing goods; ${ }^{97}$ and seizure, forfeiture and destruction of materials and implements the predominant use of which has been in the commission of the offense. ${ }^{98}$

The Copyright Act of Bangladesh fulfilled the provisions of TRIPS Agreement, by this agreement there are three kinds of remedies against infringement ${ }^{89}$ WIPO (1988), Background Reading Material on Intellectual Property, WIPO Publication No. 659(E) p. 288.

${ }^{90} \mathrm{Md}$. Milan Hossain, Present Situation of Copyright Protection in Bangladesh, Bangladesh Research Publications Journal, Volume: 7.

${ }^{91}$ International Intellectual Property Alliance (IIPA) 2009 Special Report on Copyright Protection and Enforcement Copyright Protection Situation in Bangladesh available at http://www.bdresearchpublications.com/journal/ (visited on 5.4.2017 at 9.34pm)

${ }^{92}$ Article 41.1, TRIPS Agreement 1994.

${ }^{93}$ Article 44, ibid.

${ }^{94}$ Article 46, ibid.

${ }^{95}$ Article 46, ibid.

${ }^{96}$ Article 61, ibid.

${ }^{97}$ Article 61, ibid.

${ }^{98}$ Article 61, ibid. 
and piracy of copyright has been specified, namely:

\section{1) Civil remedies}

The owner of the copyright can bring civil action in which relieves such as Anton Pillar Order ${ }^{99}$ or (Search Order) injunction, accounts and damages can be sought. ${ }^{100}$

A suit or other civil proceedings relating to infringement of copyright is to be filed in the Court of District Judge, ${ }^{101}$ within whose jurisdiction the plaintiff resides or carries on business or where the cause of action arose irrespective of the place of residence or place of business of the defendant Civil suits provides remedy for claiming compensation for infringement of copyright and loss of profits as well. ${ }^{102}$

Anton Pillar Order ${ }^{103}$ is very important to prove the infringement. Thus, the copyright office in collaboration with custom authorities can inspect any vehicle, ship, air-craft, dock or premises on the basis or a complaint lodged by the owner of a copyright or his duly authorized agent and can take action to prevent importation of illegal copies of the copyright materials.

\section{2) Criminal remedies}

The owner may initiate criminal proceedings against the alleged infringer under the provisions of this Act of 2000. The Act has incorporated certain acts as offences: ${ }^{104}$

i. willful infringing or abetting the infringement of the copyright in a work other than in the case of cinematograph film; or ${ }^{105}$

ii. willful infringing or abetting the infringement of the copyright in a cinematograph film; or ${ }^{106}$

iii. infringing the copyright in a work of computer program, publishing it in any medium, selling or distributing it more than one copy; or ${ }^{107}$

iv. using an infringed copy in computer. ${ }^{108}$

The present Act provides criminal remedies under above circumstances for the imprisonment of the accused or imposition of fine or both, seizure of infringing copies etc. in the following ways: ${ }^{109}$

Firstly: The infringement of copyright is a cognizable offence and is punishable with imprisonment for a period extending from six months to four years and a fine ranging from Tk. 50,000/- to Tk. 200,000/-. ${ }^{110}$

\footnotetext{
${ }^{99}$ Anton Pillar Order is in nature of interlocutory remedy which would allow a victim of copyright infringements to enter the premises of the infringer and seize the infringed articles including instruments of infringement. This remedy was first given to a British case-Anton PillervManufacturing Process.

${ }^{100}$ Section 76, the Act of 2000.

${ }^{101}$ Section 81, Ibid.

${ }^{102}$ Ibid.

${ }^{103}$ Anton Piller K.G. vs. Manufacturing Process Ltd. (1976) RPC 719.

${ }^{104}$ Sections 82-84, the Act of 2000 .

${ }^{105}$ Ibid.

${ }^{106}$ Ibid.

${ }^{107}$ Ibid.

${ }^{108}$ Ibid.

${ }^{109}$ Section 82, Copyright Act 2000.

${ }^{110}$ Ibid.
} 
Secondly: The Act provides for seizure of infringing copies and confiscation of all duplicating equipment used for manufacturing counterfeit copies. ${ }^{111}$ However, if the court ${ }^{12}$ is satisfied that infringement is committed without having an intention for profit or non-commercial purpose, the court may give lesser punishment, which may be imprisonment for less than six months and fine for less than 50,000 taka. ${ }^{13}$

Thirdly: In case of piracy of computer programs, the amount of fine is extended by an amendment to the Copyright Act on May 18, 2005, which is now minimum Tk. 100,000 and maximum Tk. 400,000, if it is committed for commercial purpose. ${ }^{114}$ However, in case of mere use of infringing copy or if the court is pleased that it is committed for non-commercial purposes; the court may impose lesser punishment and reduce fine as well.

\section{3) Administrative remedies}

Any person aggrieved under the Copyright Act may apply to the Registrar to ban the import of infringing copy into Bangladesh which is another important remedy for the owner of the work as administrative remedy, when the infringement is by way of such importation and the delivery of the impounded infringing copies to the owner of the copyright. Counterfeit/pirated goods, can, if it is proved by the court as an act of infringement, be destroyed by the administrative authority. ${ }^{115}$

\section{j. Copyright Board}

The Copyright board is a juristic body constituted under Copyright Act, $2000^{116}$ to discharge the judicial functions under this Act. The Board shall consist of a chairman and two or more members but not exceeding six members. ${ }^{117}$ They shall be appointed for a term not exceeding five years. The Chairman of the Copyright Board shall be a person who is or has been a Judge of High Court Division or is qualified for appointment as a Judge of the High Court Division of Bangladesh. ${ }^{118}$ The Registrar of copyrights shall be the Secretary of the Copyright Board and shall perform such functions as may be deemed to be a Civil Court. ${ }^{19}$

The Copyright Board shall perform the following functions mainly:

- To decide whether a work has been published or as to the date on which the work was published for purpose of determining the term or copyright. ${ }^{120}$

- To decide whether the term of copyright for any work is shorter in any other country than under the Act. ${ }^{121}$

- To settle disputes arising in respect of assignment of Copyright under this

${ }^{111}$ Section 93, Copyright Act 2000.

${ }^{112}$ Court of Sessions.

${ }^{113}$ Section 93, Copyright Act 2000.

${ }^{114}$ Section 84, ibid.

${ }^{115}$ Available at, http://www.thedailystar.net/law/2006/02/01/education.htm, Copyright Protection Situation in Bangladeshvisited on 05.05.2017 at $9.35 \mathrm{pm}$.

${ }^{116}$ Section 11, Copyright Act, 2000.

${ }^{117}$ Ibid.

${ }^{118}$ Ibid.

${ }^{119}$ Ibid.

${ }^{120}$ Section 6, Copyright Act, 2000.

${ }^{121}$ Section 6, ibid. 
Act. $^{122}$

- To settle disputes regarding share right in the resale of original copies. ${ }^{123}$

- To grant compulsory licenses in respect of Bangladeshi works withheld from public. $^{124}$

- To grant compulsory licenses to publish an unpublished work. ${ }^{125}$

- To grant compulsory licenses to produce and publish translation of literary and dramatic works. ${ }^{126}$

- To grant compulsory licenses to reproduce and publish certain categories of literary, scientific or artistic works for certain purposes. ${ }^{127}$

- To certify the Register of Copyrights by: ${ }^{128}$

$>$ The making of any entry wrongly omitted to be made in the register, or

$>$ The expunging of any entry wrongly made in, or remaining on, the register, or

The correction of any error or defect in the register.

- An Appeal from any order of the Board shall lie to the High Court Division and such an appeal must file within three months from the date of decision. ${ }^{129}$ But the decision given by the Board under section 6 of the Act shall be final and no appeal shall lie from that decision. ${ }^{130}$

- The Act also laid down that the Registrar of Copyrights and the Copyright Board shall have the powers of a civil court when trying a suit under the Code of Civil Procedure, 1908, in respect of the following matters, namely: ${ }^{131}$ summoning and enforcing the attendance of any person and examining him on oath,

$>$ requiring the discovery and production of any document,

$>$ receiving evidence on affidavits,

$>$ issuing commissions for the examination of witnesses or documents, requisitioning any public record or copy thereof any court of office,

Any other matter which may be prescribed.

- The Act also referred that every order made by the Registrar of Copyrights or the Copyright Board under this Act for the payment of any money or by the High Court Division in any appeal against any such order of the Copyright Board shall be deemed to be a decree of a Civil Court and shall be executable in the same manner as a decree of such court. ${ }^{132}$

\section{k. Collective Administration of Copyright and Copyright Society}

The Act contains a number of provisions for the collective administration of Copyright. Collective administration of the Copyright means the management

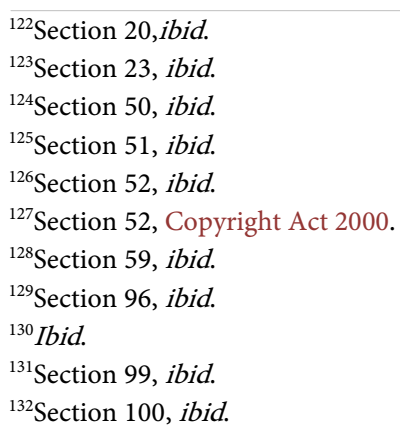


and protection of copyright in a society of owners of such creation. It also discusses about the formation and management of Copyright society in Bangladesh. ${ }^{133}$ An owner alone is not able to keep all the records of the uses of his works. ${ }^{134}$ But if the records have been kept by any society as a whole, the owner would have a better position to keep the records of the use of his work due to the organizational facilities and strength. But it is strange to see that no Copyright society has formed yet in our country.

\section{Reasons for Ineffective Copyright Enforcement in Bangladesh}

The protection and enforcement of Copyrights has been a matter of great concern in Bangladesh. The general public is not even aware of what Copyrights actually means. And the very few laymen, who have heard something about it, mostly cannot differentiate between a trademark, copyright and a patent. The remaining who actually know about it, do not fear from infringing these rights as the enforcement mechanisms are inefficient and ineffective.

Even though the Copyright Act provides strong enough provisions to convict a person or a group for copyright infringement, the procedural structure of the Bangladesh system has always been a hurdle to deter piracy. Bangladesh still remains on the Priority Watch List for the following reasons:

i. Policing and Less Number of Suo-moto Raids: In order to provide better copyright enforcement in sub-continent, the police have to play an extremely important role. However, a majority of the Police personnel in the Crime Branch or copyright cells in most of the states are not familiar with the provisions of the copyright act. Police gives priority to other civil and criminal cases than to copyright infringement cases as they are unable to realize the seriousness of such an issue because of lack of training in this particular field. Moreover, when the raids occur, the information about the raid is leaked themselves by some of the police officers to the pirates.

ii. The Lack of Judicial System: A prominent law researcher for Human Resource Development has said that, "The Sub-continental Judiciary has the onerous responsibility of interpreting the balance between private interests and public welfare". ${ }^{135}$ The Judicial System comprises of around 2200 courts across the country. ${ }^{136}$ The court procedures are also very slow and cumbersome. Penalties are inadequate; there are delays in case preparation and prosecution. ${ }^{137}$

iii. Lack of Training to the Police: It is necessary to have police education and public awareness in order to strengthen controls on piracy. As mentioned in various papers, the police officials have lack of necessary amount of training

${ }^{133}$ Section 42 of Copyright Act, 2000

${ }^{134}$ Chapter VIII Sections 41-47 of Copyright Act, 2000.

${ }^{135}$ See Press Information Bureau, discussing that it is the responsibility of the Indian judiciary to interpret the copyright law and maintain a balance between public and private interests.

${ }^{136}$ Ministry of Law Justice and Parliamentary Affairs of Bd.

${ }^{137}$ Md. BalayetHossain, Criminal Procedure Code, 1898; Dhaka: Book Publication p.44. 
in the field of Intellectual Property.

iv. Lack of Legal Frameworks: As required copyright laws of Bangladesh till now not ensured. Because of the existing ineffective copyright laws the status of copyright of Bangladesh going to the backdoor of the end of justice. Due to the lacking of necessary laws for the protection of the copyright of the author or owner they are not facing safe to enhance their intellectual created works.

v. Limited Dissemination: Copyright protection forbids individuals other than the owner from reproducing, displaying or performing the protected work for any purposes. Therefore, copyright protection may prevent owner's work from being disseminated as broadly or as quickly as anyone might like. This is primarily a disadvantage of the existing copyright laws of Bangladesh for an author seeking public attention rather than financial gain.

vi. Limited Protection: Copyright Act 2000 offers limited protection for the owner or creator. For example, copyright protects a particular expression of an idea (as in images, words or sounds) but it does not protect the idea or concept itself. Thus, if someone draws a picture of a new type of shower head, others will be prohibited from copying the drawing, but they can still use the basic idea to build an actual shower head.

vii. Limited Duration: Copyright protection does not last endlessly. The duration depends on several factors. It's also a most imperative lacuna of the existing Copyright Act 2000.

viii. Lack of Public Awareness: One of the important factors of inefficient copyright enforcement is that the people are not aware of this problem. A person who watches a latest Dallywood or Hollywood movie on the cable, or buys a best seller from the street, or downloads latest music from the computer and makes his own MP3 to play it in his restaurant does not even have a hint that he infringing someone's rights. It is important that the public must have knowledge about the role of intellectual property in the growth of the country and the seriousness of the offence if they infringe such rights. ${ }^{138}$

ix. Non Establishment of Copyright Society: There is a provision of the establishment of copyright society in Bangladesh, but unfortunately till now it was not established.

x. Delay Disposal of the Case: Owners of the copyrights are day by day losing their faith in the action of judiciary because of the delay disposal of their proceedings. On the other hand, the pirates are taking the benefit of this lethargy procedure.

\section{Recommendations}

Copyright Piracy is a great challenge in ensuring copyright protection in a country. The present laws of copyright are compliance with international laws or agreements but in spite of that piracy rate is the highest in Bangladesh amongst the world. Lack of awareness and proper implementation of the laws are mainly

\footnotetext{
${ }^{138}$ See http://www.srmuniv.ac.in/applications.
} 
liable to such position. IIPA ${ }^{139}$ requests most of the Governments the world to take the following actions, which would result in the most significant near term commercial benefits to the copyright industries.

In the light of the above discussion following recommendations are proposed for Copyright system of Bangladesh:

- Establish an anti-piracy force and take actions (including ex officio) against book piracy at photocopy shops and those who engage in offset printing and against rampant CD, DVD, CD-R, DVD-R and CD-ROM piracy.

- Establish a cell within the Bangladeshi Customs to intercept imports and exports.

- Inspect of all optical disc plants, collecting exemplars and closing down plants engaged in piracy, seizing pirate discs and materials, and prosecuting owners and other related persons of pirate.

- Copyright law should provide basis for the protection of software because absence of copyright protection in software is accountable for poor flow of foreign client and extremely low rate of export of software which is not ensured in Copyright Act of 2000. ${ }^{140}$

- Along with the copyright protection suitable mechanism should be in place for prevention of infringement. The act should also stipulate the examples and amount of infringement of the copyright in computer software and other online basis.

- Legal system should be equipped with proper exampled and instrument to deal with sophisticated litigation over the ownership of copyright in software and other computer basis. Besides, technically qualified judicial persons like judge should be provided to settle disputes relating to this area.

- Mechanism must be developed to ensure speedy and cheap resolution of disputes and litigation by infringement where the existing proceedings are not well equipped.

- Step should be introduced to establish a private central copyright society, which should act as ombudsman against infringement of software copyright and at the same time safeguard proper marketing of software and maximum license fees.

- In the universities syllabus intellectual property right should be introduced as a part of undergraduate education course to make the future Information Technology experts who will be aware of the copyright law.

- Dissolve backlogs (Intellectual Property judges or courts should begin free of backlogs); enforce deadlines for adjudication/resolution of piracy cases, and prevent unjustified continuances of the case; encourage completion of a set number of "model" cases with deterrent punishments to deliver a message to the public about piracy; adopt case management techniques (we understand ${ }^{139}$ IIPA indicates International Intellectual Property Alliance.

${ }^{140}$ The DCCI CIPE, ERRA Project, ECONOMIC POLICY PAPER ON Copyright, Trademark and Patent Protection, Available at,

http://www.dhakachamber.com/economic_policy/Copyright_Laws-Final.pdf (visited on 20/04/2017 at $9.39 \mathrm{pm})$. 
progress has been recently made on this and on instituting plea bargaining); and, treat piracy as a serious economic crime.

- Specialized Intellectual Property courts and Intellectual Property judges shall be appointed. The copyright cases are brought to the same courts as the other civil or criminal cases which are large in number. These results in ignorance or delay in the adjudication of copyright cases.

- The people of the country need to get aware of the importance of copyright laws and their effects, not only on the creative and innovative thinking of the authors but also on the national economy of the country. The government should take necessary measures to promote copyright enforcement by telling people about the harms of copyright violation.

- Creating awareness through seminar, symposiums and national workshops among the all classes educated people of the country.

- Establishing copyright courts, at least, in the divisional level and training the judges and thus making the experts.

- Developing mechanism to ensure speedy and cheap resolution of disputes and litigation by infringement.

- Employing special teams of the members of law forces for the implementation of the copyright laws and training them.

\section{Contributions and Significances of This Research}

By this research the following persons and authority shall be benefited, namely:

a. The govt. can take necessary steps to reduce the existing lacunas of the Copyright Act, 2000;

b. The govt. can introduce new effective laws for the protection of the owner or creator of the copyright works;

c. Judges who are authorized under Copyright Act to settle the disputes related copyright the can also be benefited in solving their disputes;

d. Advocates or prosecution can be benefited in dealing with their case which are relating to copyright;

e. Legislature, and stakeholders shall be benefited by the outcome of this research in dealing with the copyright matters;

f. Teachers, students, researcher and other readers will also be benefited by this research in regarding of their copyright expertness;

g. Pirates will get a treat for his activities by knowing the rigid punishments of the law against his unlawful activities.

\section{Scope for Further Research}

From this research the following scopes for further research may be created, namely:

a. This research only deals about the existing copyright status of Bangladesh under Copyright Act 2000 with its problems and recommendations; so there are a lot of scopes for other researchers to research with the Future Copyright Laws of Bangladesh or Amendment of the Existing Copyright Laws of Ban- 
gladesh.

b. Other researchers can research with the court structure of copyright, qualification of the judges, awareness of the advocates relating to the cases of copyright.

c. This research creates a new scope for the researcher to research in the fields of establishment of the copyright society.

d. Again the researcher can research in the field of establishing strong copyright protection authority.

e. There are also scopes for the researcher to do a comparative study among the copyright laws in Bangladesh and the copyright laws in any of the developed countries e.g., USA, UK, Canada, etc.

\section{Conclusion}

In Bangladesh, due to the lack of consciousness and execution of the legal system of copyright laws, the actual authors are not getting any benefits of their intellectual works. It is too bad not only for actual authors but also for whole country. So the person who copies should be punished and actual authors should be much more conscious as horse. The Act 2000, the (Amendment) Act, 2005 and the Rules 2006 are passed in order to safeguard standard protection to the creators and authors of copyrights in compliance with the international aspects like as WIPO and TRIPS and also Ben Convention. It can be noted that the present law maintains the standard level in case of Copyright. But we still have to go a long way in terms of awareness, utilization and practice of copyright. Bangladesh is following the works of India and China who are the highest rated countries in the world in cases of software piracy. In order to strengthen copyright protection or to reduce the import of piracy works, it is important that every educated citizen must have awareness and a basic understanding of the notion of copyright. It can be said that citizens' understanding of copyright helps to develop the country's unique cultural activity. Proper implementation of the copyright laws, incorporating cyber laws in the copyright laws and increasing respect for copyright must bring cultural and economic development to the country which will make us as a civilized nation in the world of today.

\section{References}

Anton Piller K.G. vs. Manufacturing Process Ltd. (1976). RPC 719.

Azam Mohammad Monirul (2008). Intellectual Property WTO and Bangladesh (1st ed., (pp. 188-213). Dhaka: New Warsi Book Corporation

Berne Convention on WIPO.

Copyright Act 2000 (Act No. XXVIII).

International Intellectual Property Alliance (IIPA) (2009). Special Report on Copyright Protection and Enforcement. Copyright Protection Situation in Bangladesh.

Md. Milan Hossain. Present Situation of Copyright Protection in Bangladesh. Bangladesh Research Publications Journal, 7.

Narayanan, P. (2001). Intellectual Property Law (3rd ed.). Kolkata-New Delhi: Eastern Law House. 
Owen, L. (2001). Piracy Association of Learned and Professional Society Publishers 14(1).

Patents and Designs Act, 1911.

Press Information Bureau. Discussing that it is the responsibility of the Indian judiciary to interpret the copyright law and maintain a balance between public and private interests.

SayeedRaasMaswod (2010). A Handbook on Laws of Intellectual Property(1st ed.). Dhaka: University Publication.

Sims vs. Marrayat, 17 CB 281; 20 LJQB; 79 ECL 281.

The DCCI CIPE, ERRA Project (2000). Economic Policy Paper on Copyright, Trademark and Patent Protection.

http://www.dhakachamber.com/economic_policy/Copyright_Laws-Final.pdf

TRIPS Agreement 1994.

WIPO (1988). Background Reading Material on Intellectual Property (pp. 207-264). WIPO Publication No. 659(E).

Submit or recommend next manuscript to SCIRP and we will provide best service for you:

Accepting pre-submission inquiries through Email, Facebook, LinkedIn, Twitter, etc. A wide selection of journals (inclusive of 9 subjects, more than 200 journals)

Providing 24-hour high-quality service

User-friendly online submission system

Fair and swift peer-review system

Efficient typesetting and proofreading procedure

Display of the result of downloads and visits, as well as the number of cited articles

Maximum dissemination of your research work

Submit your manuscript at: http://papersubmission.scirp.org/

Or contact blr@scirp.org 